\title{
Rajaswala Paricharya: an Ayurvedic Management to Prevent Menstrual Disorders.
}

\author{
Vd. Rutuja S.Gaikwad ${ }^{1}$. Vd. Rekha C Kuwar ${ }^{2}$, Vd. Sayali Pashte ${ }^{3}$ \\ ${ }^{1}$ Assistant Professor, Streeroga Prasutitantra Dept., R.A.Podar Medical (Ayu.) College,Worli, Mumbai-18. \\ ${ }^{2}$ Assistant Professor, Streeroga Prasutitantra Dept., R.A.Podar Medical (Ayu.) College,Worli, Mumbai-18. \\ ${ }^{3}$ PG-Scholar, , Streeroga Prasutitantra Dept., R.A.Podar Medical(Ayu.) College, Worli, Mumbai-18.
}

\begin{abstract}
Due to changing lifestyle, physical and mental stress and bad food habits, women in the reproductive age group suffers from various conditions related to menstrual cycle like menorrhagia, dysmenorrhea, irregular menses, PCOD, endometriosis etc. which seriously affect her health and happiness and also proves to be great discomfort. It increased incidence of infertility also. Hence an urgent need is seen to educate the society regarding the various Paricharyas (mode of living) put forth in ayurveda in order to maintain the doshas, which in turns maintains health. Most neglected paricharya- 'Rajaswala Paricharya" if followed during menstruation, it will helps women to respond healthily to the drastic physical and mental changes during menstrual cycle and in relieving symptoms associated with it.
\end{abstract}

Keywords: Rajaswala, Paricharya, Menstrual cycle, Lifestyle.

\section{Introduction}

Throughout the life journey, women have to be passed from three phases - Bala (childhood), Rajaswala (menstruation/reproduction phase) and vriddha (Old age-menopause). Out of these Rajaswala period is largest and most important period as it is fertile period necessary for reproduction. If this phase is healthy then it will give better progeny.In present era, women are now working. Along with their careers, they alone manage household responsibilities. This has made life of women busier and hectic than it was before. This demanding lifestyle has made it very difficult to pay attention on their own health and it disturbed normal menstrual cycle causing serious disorders related to it.

Ayurveda helps women to gain better health and quality to her life by following Paricharyas. Paricharyas- is conduct to be followed during different phases of life like Rajaswala Paricharya, Garbhini Paricharya and Sutika Paricharya. In past knowledge about such paricharyas were passed down from one generation women to other. Due to formation of nuclear families, aversion towards ancient tradition and western way of living this knowledge has lost. So in $20^{\text {th }}$ century it has been observed that menstrual problems increased and also incidences of infertility increased. So it is necessary to follow again ancient Rajaswala Paricharya to get relief from such conditions and to gain better healthy life.

\section{Causes of increased incidence of menstrual disorders:}

Age plays a key role in menstrual disorders. Girls who start menstruating at age of 11 or younger are at high risk of developing dysmenorrhea and menometrorrhagia. Adolescents may develop amenorrhea before there ovulation cycles become regular.

\section{1] Causes in adolescents -}

1. Mental Stress: in competitive world stress of various examinations over young age girls which just started menstruation, causes irregularity of menses because physical and mental stress causes hormonal imbalances.

2. Exercise : excessive physical stress it may be due to excessive sports activities or over burden of exercises over body for losing over gained weight by fatty girls. It increases the risk of amenorrhea or oligomenorrhea.

3. Weight loss: Eating disorders are common cause of amenorrhea in adolescent girls. Extreme weight loss and reduced fat stores leads to hormonal changes that include low thyroid levels (hypothyroidism) and elevated stress hormone levels (hypocorticosteroids).

4. Obesity :Due to wrong food habits such as habits of eating junk food, oily food, bakery products and irregular meal times incidence obesity is increased which impacts on menstrual cycle further casing PCOD like metabolic disorders. 


\section{2] Causes in reproductive age group women:}

In reproductive age group women increased incidence of advanced diseases like PCOD, uterine fibroids, adenomyosis endometriosis, pelvis infections, etc causes menstrual abnormalities.

1. The factors like Wrong diets, overweigh or weight loss causes menstrual disorders in this age group women.

2. Working women: having physical and mental stress develops menstrual disorders.

3. Birth control pills: Easily availability and so increased repeated use of hormonal pills is one of the leading cause of menstrual abnormalities.

\section{Rajaswala paricharya mentioned in various ayurvedic granthas:-}

Rajaswala paricharya - a mode of living during menstruation is mentioned various ayurvedic granthas such as charaka samhita, sushruta samhita, kashyapa samhita, ashtanga hridyam, ashtang sangraha and bhava prakasha.

\section{Activities contraindicated are :}

1. Avoid seeping during day time. She should be sleep over bed made up of darbha (specific sacred leaf plant) spread over ground.)

2. Application of anjana, crying, massaging, laughing, talking too much and exercise should be avoid.

3. Use of Swdana karma, Vamana and nasya karma are contraindicated.

4. Diet contraindicated: Avoid pungent (tikshna), spicy (katu) and salty food.

5. Coitus is contraindicated.

6. No adorn oneself, not wear ornaments.

\section{Indicated activities and diet:}

1. Always concentrate on thinking good and auspicious things.

2. should eat havishya ( meal made up of ghee, Sali rice and milk) and Yawaka (meal made up of barley and milk ) in utensils made up of clay and leaves.

Consequences due to non-avoidance of restricted acts mentioned in granthas:

If women does not avoid earlier described acts due to ignorance and neglect, the vitiated doshas reaching the foetus produce following abnormalities-

\begin{tabular}{|l|l|}
\hline Restricted activities & Abnormalities in child \\
\hline Day sleeping & Over sleepy \\
\hline Use of collyrium (anjana) & Blind \\
\hline Weeping & Abnormalities in vision \\
\hline Bathing & Sad \\
\hline Oil massage & Skin diseases \\
\hline Paring of nails & Deformity of nails \\
\hline Fast running & Wanton / fickle \\
\hline Laughing & Black colour of teeth lips and tongue \\
\hline Over talking & Garrulous \\
\hline Over hearing & Deafness \\
\hline Combing & Baldness \\
\hline Exertion & Insane \\
\hline Nasya karma & Menstrual abnormalities \\
\hline
\end{tabular}

It is difficult to explain all these consequences, it may be to follow paricharya strictly due to fear of consequences. But some principles behind consequences can be consequences explain.Abnormalities in born child due to performed coitus during menses are also mentioned. It is might have possible that this might have been prescribed to deter the couples from coitus.

Principles behind Rajaswala Parichrya and its application in today's lifestyle:

1] Diet: Principle - Deepan, paachana, vatanulomana and Agnideepana.

Application - Eating in proper quantity, light diet and on regular meal time. Avoidspicy,oily diet, bakery products and junk foods.

\section{2] Avoid Fast running, Laughing and Over talking:}

Principle - Avoid exercise, take rest and restore energy to avoid vitiation of vata dosha.

Application - Avoid exercise, take rest and restore energy.

\section{3] Good and virtual thoughts, no crying:}

Principle - Avoid mental stress.

Application - Keep mind calm and relaxed as possible avoid stress and anxiety. 
4] Sleep on darbha mat and no bathing:

Principle - Instigate aseptic thoughts and decrease associated symptoms.

Application-1. Sleep on darbha mat if available to get relief from backache and bodyache.

2. Not have a complete bath - (but follow basic hygiene like cleaning genitalia,hands, legs and face.

5] No listening to loud voice:

Principle - Avoid vataprakop and rasadushti to keep mind calm.

Application - No listening to loud voice.

6] No abhyanga (massaging):

Principle - It is contraindicated in agnimandya.

Application - No abhyanga (massaging).

\section{Discussion and conclusion}

After studying Rajakala and Rajaswala paricharya, it is observed that Aacharyas treated Rajakala as a natural shodhana kala, leading to agnimandya.According to Ayurveda, menstruation is a naturally occurring shodhana procedure occurring monthly so it is necessary to follow pathya and apathya mentioned under shodhana therapy which are similar to the rajaswala paricharya. Aim of this is avoid vitiation of vata and $k a p h a$, prevent formation of aama and restore energy. Thus following rajaswala paricharya women respond healthily to the physiological and psychological changes by keeping balance doshas, agni and bala. Rajaswala paricharya is best example of nidana parivarjana chikitsa (Prevention of diseases) so by following paricharya, we can counter the adverse effects of present life style over reproduction by avoiding menstrual disorders.

\section{References}

[1]. Vridhajivaka, Kashyap Samhita with Vidyotini Hindi Commentary by D.S. Bahishjyaratnamani, $8^{\text {th }}$ Edition Chauckhamba Prakashan, Khilasthana, chapter 11 verse no. 6.

[2]. Vridhajivaka, Kashyap Samhita with Vidyotini Hindi Commentary by D.S. Bahishjyaratnamani, $8^{\text {th }}$ Edition Chauckhamba Prakashan,. Khilasthana, chapter 11, pg no 308

[3]. BhaavMishra, 'Bh $\square \mathbf{v}$ Prakasha' Part-1 Vidyotini Hindi commentary by Bramhasankara Misra \& Rupalalji Vaisya, Ninth edition, Coukhambha Sanskrit Sansthan, madhyama khanda sutrasthana 35 .

[4]. 4.Sushrutaacharya, Sushrut samhitaa with Nibandhsangraha commentary of Sri Dalhanaacharya edited by yadavji trikamji acharaya, eigth edition, Chaukhamba Orienatalia, sharirasthana, chapter no. 2-verse no 25, chapter no 2-verse no. 31.

[5]. Caharakaacharya, Charak Samhitaa, with hindi commentary 'Vaidya manorama' by Acharya Vidyadhar Shukla and Prof. Ravi Dutt Tripathi, Second edition, Chaukhamba Sanskrit Pratishthan, sharira sthana, chapter 8, verse no. 5.

[6]. Vagbhatacharya, Ashtang Hrudaya with commentaries Sarvang Sundara of Arundatta and Ayurvedarasayana of Hemadri, Reprint edition, Krishnadas Academy, sharirasthana, chapter no.verse no. 5 and 45.

[7]. Sharangdharaacharya, Sharangdhar Samhita with dipika hindi commentary by Brahmanand Tripathi, reprint edition, Chaukhamba Surbharati prakashan,

[8]. Dr. Premvati. V. Tewari, Ayurvediya Prasuti Tantram Evam Stree Roga, second edition, Chaukhamba orientalia.

[9]. Priyavatt Sharma, Dravya guna Vidnyan, part II, chaukhambha Bharati Academy. 